\section{The American Political Science Review: \\ A Retrospective of Last Year and the Last Eight Decades}

\author{
Samuel C. Patterson \\ Brian D. Ripley \\ Barbara Trish \\ Ohio State University*
}

* We appreciate the assistance of Jean Walen and the comments and suggestions of Clarence Berdahl and R. Taylor Cole.

It is customary these days for the manag. ing editor of the American Political Science Review to report each year to the APSA Council, and to the membership in general, on his or her stewardship of the journal. In one way or another, managing editors have been doing this since the founding of the Review in 1906. In this report we have chosen both to perform the duty of adumbrating the nuts and bolts of Review work in the past year, and to survey the development of the Review since its first managing editor, W. W. Willoughby, reported to the APSA Executive Council in the early years of this century.

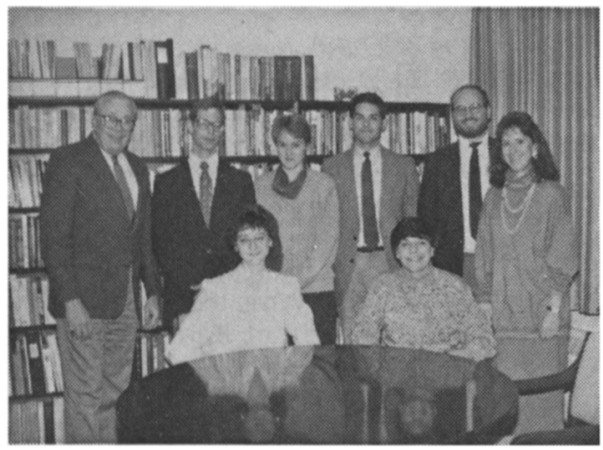

I. to r., Samuel C. Patterson, APSR Managing Editor; Michael K. Lane, Copy Editor; Sharon E. Heinrich (seated), Editorial Assistant; Barbara Trish, 1987-88 intern; Kevin T. McGuire, 198889 Intern; Jessica R. Adolino (seated), 1988-89 Intern; Brian D. Ripley, 1987-88 Intern; and Jean P. Kelly, Assistant Editor.
The State of the Review

The staff of the Review continues to work with manuscripts of very high quality in order to publish a quarterly journal of exceptional merit. In this enterprise, the staff at Ohio State University gets the professional help of scores of colleagues in colleges and universities around the world who make the peer review system work. In addition, the Review is greatly assisted by the staff of the Washington office of the American Political Science Association, by Tom and Cheryl Mullings who compose the Review in Columbia, Maryland, and by Banta Printing Company in Menasha, Wisconsin, where the journal is produced (and has been since 1926).

At the Review offices at Ohio State University, Samuel C. Patterson continues to serve as managing editor. Assistant Editor Jean P. Kelly manages the day-to-day complexities of the Review, supervises the development of each quarterly manuscript, and works with authors and editors to transform the manuscript into an issue of the journal. Copy Editor Michael K. Lane does the major editing of articles and book reviews. For 1987-88 the APSR graduate interns have been Barbara Trish and Brian D. Ripley; for 1988-89 the interns will be Kevin McGuire and Jessica Adolino. Michelle A. Colter has served as editorial assistant during the past year. Helen $M$. Ingram, University of Arizona, has been serving as book review editor since October 1987. Finally, Patricia A. Manning worked as a book review intern during the past year.

At any one time, the Review staff is working on four issues of the journal, each at a different stage of production. For instance, when an issue is in press or in print, the next issue is at the galley proof or page proof stage. A third issue, a manuscript of about 850 pages, is being copyedited for the compositer, while we are accepting manuscripts for a fourth issue. That is the normal flow of our work in producing the Review. Every three months we take pride in seeing the research and writing of a new set of authors handsomely published. 
Figure I. Submissions by Month, 1987-88

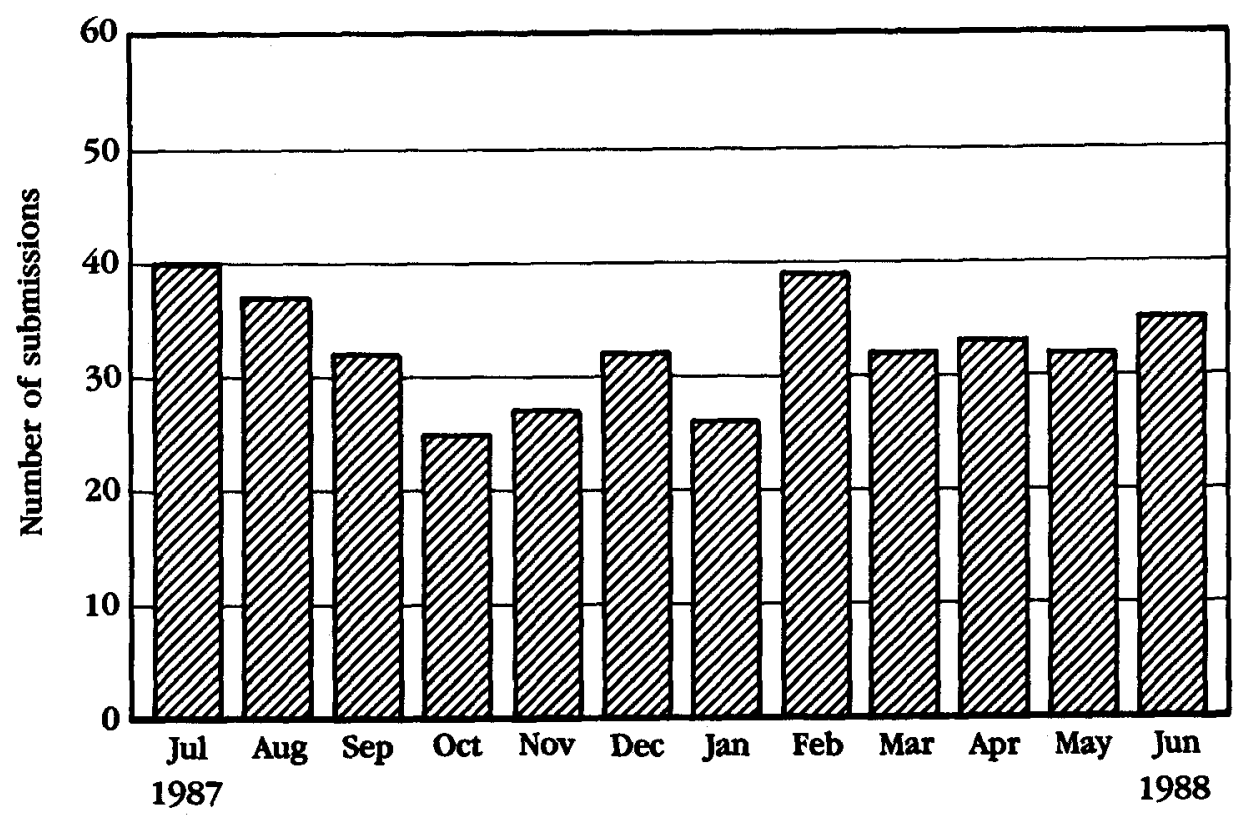

\section{The Flow of Manuscripts}

Every year we evaluate our effectiveness in processing manuscripts and publishing the best products of the peer review process. This annual reporting has become fairly standardized, enough so that a time series in fairly detailed performance evaluation has emerged over the past few years. Assessment of the performance of the Review staff has come to be monitored in terms of established criteria of manuscript submission flow, the operation of the peer review system, and the book review program.

Submissions. From July 1987 to the end of June 1988 the Review received 39/ submissions, closely matching the 394 submissions for the comparable 1986.87 year. Firsttime, full-length manuscripts continue to be the most common form of submission (320), but revisions are gaining in popularity. The 1987-88 revision level is 54 , twice the year-long total of 27 for 1986-87. Papers submitted as controversies and research notes are still relatively infrequent with only 7 and 10 submissions, respectively. However, we frequently urge authors to transform their full-length manuscripts to take advantage of the unique opportunities offered by the Review's controversy and research note sections. This explains their consistent publication in the APSR since 1986 despite low submission levels.

The Review receives an average of 32 submissions each month although, as Figure I shows, there is some secular fluctuation. In the absence of a compelling explanation for the variation in submission levels, we attribute it to idiosyncratic behavior of authors.

The breakdown of submissions by substantive field for the current year and the past four years is shown in Table 1. The area called "political behavior" in previous reports has been renamed "formal theory" to reflect more accurately the coding scheme applied. For this reason, the current figures may not be strictly comparable with previous ones. One rather dramatic change since the 1986-87 period is the increase in submissions in comparative politics. Seven percent higher than 1986-87, the comparative area now ranks second among all subfields. Submissions in American politics are consistently high compared to other areas, although 
Table 1. Submissions by Substantive Field

\begin{tabular}{|c|c|c|c|c|c|c|}
\hline \multirow[b]{2}{*}{ Field } & \multirow{2}{*}{$\begin{array}{c}1983-84 \\
\%\end{array}$} & \multirow{2}{*}{$\begin{array}{c}1984-85 \\
\%\end{array}$} & \multirow{2}{*}{$\begin{array}{c}1985-86 \\
\%\end{array}$} & \multirow{2}{*}{$\begin{array}{c}1986-87 \\
\%\end{array}$} & \multicolumn{2}{|c|}{$1987-88$} \\
\hline & & & & & $\%$ & $\mathbf{N}$ \\
\hline $\begin{array}{l}\text { American politics } \\
\text { Comparative politics } \\
\text { International relations } \\
\text { Political theory } \\
\text { Methodology } \\
\text { Formal theory } \\
\text { Public policy and }\end{array}$ & $\begin{array}{r}25.0 \\
12.5 \\
9.6 \\
16.4 \\
9.9 \\
20.1\end{array}$ & $\begin{array}{r}23.1 \\
12.8 \\
7.2 \\
17.5 \\
8.8 \\
23.4\end{array}$ & $\begin{array}{r}31.0 \\
14.1 \\
8.6 \\
22.6 \\
2.2 \\
12.1\end{array}$ & $\begin{array}{r}33.5 \\
11.5 \\
10.8 \\
23.0 \\
2.5 \\
8.0\end{array}$ & $\begin{array}{r}32.5 \\
18.2 \\
9.5 \\
16.6 \\
5.9 \\
10.2\end{array}$ & $\begin{array}{r}127 \\
71 \\
37 \\
65 \\
23 \\
40\end{array}$ \\
\hline administration & 6.2 & 7.2 & 9.4 & 10.7 & 7.2 & 28 \\
\hline Total & 99.7 & 100.0 & $100.0 \%$ & $100.0 \%$ & 100.1 & 391 \\
\hline
\end{tabular}

down slightly from the previous year. Political theory has returned to its normal position after a brief surge in submissions in the previous two years.

Acceptance Rate. Final decisions were made on 401 manuscripts between I July 1987 and 30 June 1988. Total decisions and total submissions for this period overlap but do not completely correspond. Of the decisions, $13 \%(51)$ were accepted for publication, $11 \%$ (44) returned to the author with a request to revise and resubmit, and $76 \%$ (306) rejected. The breakdown of acceptance by substantive fields is shown in Table 2; essentially, these figures represent the proportion of Review space occupied by each field. American politics and political theory continue to hold prominent positions while formal theory has stabilized at a lower level than its peak three years ago.
The acceptance rates across substantive fields are shown in Table 3 . These rates reflect the number of acceptances out of the total number of decisions in each area. At $12.7 \%$ the $1987-88$ overall rate is similar to the $1986-87$ rate of $13.0 \%$. At the upper extreme, formal theory deviates considerably from the 1987-88 composite rate, one-sixth of the decisions in this area being acceptances. Although the acceptance rate for American politics is slightly higher than the composite score, this alone does not account for the large proportion of space occupied by that field. Rather, the Review ultimately prints more articles in American politics than in any other field because the high level of American politics submissions stacks the deck in its favor.

Table 2. Breakdown of Acceptances by Field

\begin{tabular}{lcccccc}
\hline Field & $\begin{array}{c}1983-84 \\
\%\end{array}$ & $\begin{array}{c}1984-85 \\
\%\end{array}$ & $\begin{array}{c}1985-86 \\
\%\end{array}$ & $\begin{array}{c}1986-87 \\
\%\end{array}$ & \multicolumn{2}{c}{$1987-88$} \\
\hline American politics & 31.0 & 20.0 & 35.3 & 40.0 & 37.3 & 19 \\
Comparative politics & 12.5 & 10.0 & 13.7 & 14.0 & 13.7 & 7 \\
International relations & 9.4 & 10.0 & 11.8 & 10.0 & 5.9 & 3 \\
Political theory & 12.5 & 17.0 & 17.6 & 20.0 & 17.6 & 9 \\
Methodology & 15.6 & 10.0 & 0.0 & 0.0 & 3.9 & 2 \\
Formal theory & 16.0 & 23.0 & 9.8 & 12.0 & 11.8 & 6 \\
Public policy and & 3.0 & 10.0 & 11.8 & 4.0 & 9.8 & 5 \\
$\quad$ administration & 100.0 & 100.0 & $100.0 \%$ & 100.0 & 100.0 & 51 \\
Total & & & & & &
\end{tabular}


The APSR: A Retrospective

Table 3. Acceptance Rates for Substantive Fields

\begin{tabular}{lccc}
\hline & \multicolumn{3}{c}{ Percentage of Acceptances in Field a } \\
\cline { 2 - 4 } Field & $1985-86$ & $1986-87$ & $1987-88$ \\
\hline American politics & $12.9(19)$ & $14.8(20)$ & $14.6(19)$ \\
Comparative politics & $9.9(7)$ & $14.3(7)$ & $10.3(7)$ \\
International relations & $15.0(6)$ & $11.0(5)$ & $7.5(3)$ \\
Political theory & $8.0(8)$ & $10.2(10)$ & $12.2(9)$ \\
Methodology & $0.0(0)$ & $0.0(0)$ & $9.5(2)$ \\
Formal theory & $8.9(5)$ & $17.6(6)$ & $17.6(6)$ \\
Public policy and administration & $13.6(6)$ & $4.3(2)$ & $14.7(5)$ \\
Overall & $10.5(51)$ & $13.0(50)$ & $12.7(51)$ \\
\hline
\end{tabular}

Note: Frequencies appear in parentheses.

a 987-88 rates based on total decisions if each field: American, 130; comparative, 68; international, 40; theory, 74; methodology, 21; formal theory, 34; public policy and administration, 34.

\section{The Peer Review Process}

The quality of the Review and the efficiency of the manuscript review process depends to a large extent on the cooperation of peer reviewers. Fully $91.8 \%$ of initial submissions that have completed the assignment process this year were sent out for review. The staff makes every attempt to be judicious in selecting the best qualified and most appropriate referees for each manuscript reviewed. Typically, each reviewed manuscript is initially assigned two or three referees. These referees' invaluable contribution to the Review is greatly appreciated.

From I July 1987 to 30 June 1988 we solicited 854 reviews for newly received manuscripts. (This count does not include referees called on to review manuscripts considered in the "revise and resubmit" category. Since revised manuscripts are often handled differently from initial submissions, their inclusion might distort the overall statistics.) Of these 854 requests for referee evaluations, we received 712 completed evaluations (83.3\%), 113 referee cancellations (13.2\%), and in 29 cases $(3.5 \%)$ we received no response from the referees. Of course, when a prospective referee declines for one reason or another, a substitute referee is assigned.

This year's cancellation rate is reasonably close to last year's rate of $12.5 \%$. As Table 4 indicates, there is some variance across fields in this regard. Fortunately

Table 4. Response Rates for Referee Cancellations (by Field)

\begin{tabular}{lcccc}
\hline Field & N & $\begin{array}{c}\text { Range } \\
\text { (Working Days) }\end{array}$ & $\begin{array}{c}\text { Median } \\
\text { (Working Days) }\end{array}$ & $\begin{array}{c}\text { Percentage } \\
\text { Canceled of } \\
\text { Total Requests }\end{array}$ \\
\hline American politics & 23 & $1-47$ days & 9 days & 8.9 \\
Comparative politics & 19 & $1-34$ days & 11 days & 12.5 \\
Political theory & 22 & $5-52$ days & 9 days & 15.5 \\
Formal theory & 12 & $5-17$ days & 10 days & 13.0 \\
International relations & 23 & $6-71$ days & 11 days & 28.0 \\
Public policy & 9 & $8-35$ days & 17 days & 18.4 \\
Methodology & 5 & $9-12$ days & 10 days & 9.8 \\
Overall & 113 & $1-71$ days & 12 days & 13.2 \\
\hline
\end{tabular}

Note: These figures correspond to files handled between I July 1987 and 30 June 1988. Manuscript revisions are not considered. 
Table 5. Response Rates for Completed Referee Evaluations (by Field)

\begin{tabular}{lccc}
\hline Field & N & Range (Working Days) & Median (Working Days) \\
\hline American politics & 234 & $4-73$ days & 26 days \\
Comparative politics & 133 & $4-81$ days & 22 days \\
Political theory & 120 & $2-72$ days & 22 days \\
Formal theory & 80 & $6-71$ days & 24 days \\
International relations & 59 & $1-61$ days & 27 days \\
Public policy & 40 & $4-73$ days & 24 days \\
Methodology & 46 & $4-66$ days & 26 days \\
Overall & 712 & 1.81 days & 24 days
\end{tabular}

Note: These figures correspond to files handled between 30 June 1987 and I July 1988. Manuscript revisions are not considered.

both for us and for anxious authors, most referees who cancel notify the Review staff within about three weeks (12 working days) of receint of the manuscript.

Scholars submitting manuscripts are often curious about how long the review process takes. Authors sometimes find that they are at the mercy of slow referees, or victims of referee cancellations despite the APSR's system of followup. As indicated in Table 5, the median number of working days required for an individual referee to return a completed manuscript evaluation is 24 working daysabout five weeks. This number varies slightly across subfields, as the table also demonstrates.

The peer review phase is typically the most time-consuming hurdle confronting a submission to the Review. The median times for peer review and the other two major phases, referee assignment and final decision, are shown in Table 6 . Clearly the 1987.88 referee phase is shorter than that of the past two years, while the preliminary step-initial processing and inhouse review of submissions--has lengthener. This expanded time frame from receipt to assignment enables us to select optimal referees and thus contributes to the short peer review period relative to past years.

Figure 2 illustrates the distribution of submission turn-around time. The modal submission takes between 8 and 10 weeks from receipt to editor's decision. While the distribution shows wide variation, we make every effort to treat each submission on its own terms.

\section{Reviewing Books}

Book Review Editor Helen Ingram has developed an effective system for handling the influx of books for review. During the past year, the book review office received I,500 books for review. Of these, 768

Table 6. Steps in the Review Process for a "Typical" Submission

\begin{tabular}{lrrr}
\hline & \multicolumn{3}{c}{ Median Time } \\
\cline { 2 - 4 } Step & $1985-86$ & $1986-87$ & $1987-88$ \\
\hline Receipt of submission to assignment & 4 days & 5 days & 11 days \\
Assignment to receipt of last referee report & 53 days & 53 days & 36 days \\
Receipt of last referee report to decision & 2 days & 3 days & 5 days \\
$\begin{array}{l}\text { Total time from receipt of submission to } \\
\text { decision }\end{array}$ & 59 days & 61 days & 49 days \\
\hline
\end{tabular}

aincludes those submissions not sent out for review. With an alternative measure, including only those submissions sent out for review, the median would be 53 days. 
Figure 2. Length of Time between Manuscript Receipt and Editor's Decision, 1987-88

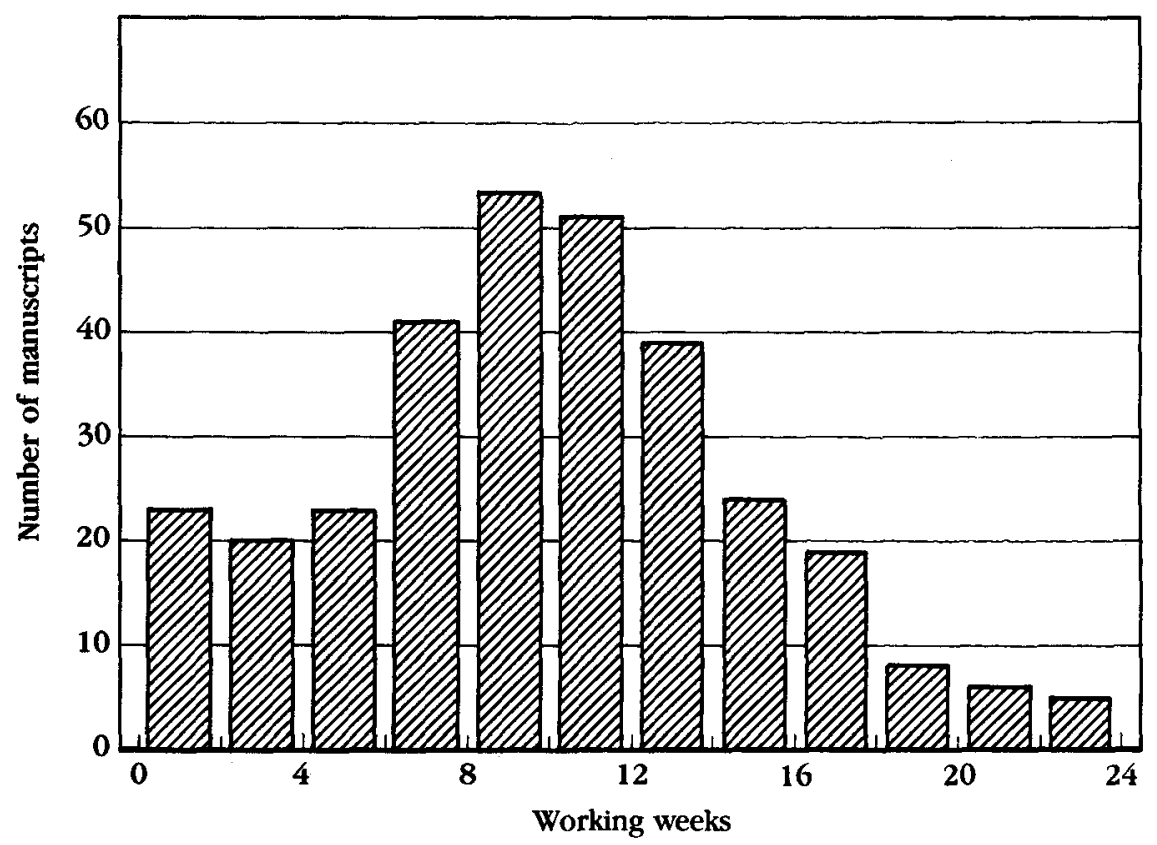

were accepted for further consideration, and 732 were rejected for review. Altogether, about one book in four is selected for review, chosen on the basis of quality and timeliness. For 1987-88, 418 books were selected for review, distributed as follows:

Field

U.S. politics

Comparative politics

International relations

Political economy

Political theory

Public policy

Others

Currently, 133 publishers are sending books to the APSR for review.

The success of the book review section depends heavily on the cooperativeness and quality of reviewers. During 1987-88, out of 523 book reviews invited, more than half $(51 \%)$ were accepted on the initial contact. For 38 percent of the invited reviews, initial contacts were not positive and an alternate reviewer was sought. Eleven percent of the books ten- dered for review were reconsidered and rejected after three or more declinations.

In volume 82,327 books were reviewed, compared to 352 books reviewed in volume 81 . Table 7 shows the distribution of books reviewed for 1988, indicating the breakdowns for each subfield. These distributions have not oscillated substantially in recent years. Moreover, the subfield distributions of books reviewed roughly shadows that of books received from publishers or authors except that books in the American politics field seem to be reviewed at a somewhat higher rate than is true for other areas.

With the current volume we begin the publication of review essays featured more distinctly as articles rather than incorporated into the book review section as in the past. In these review essays, Book Review Editor Ingram plans to feature commentaries and assessments of major books in political science, offered by major scholars in the relevant field. The September 1988 issue carried an essay by Byron Shafer (September 1988). Future issues will include essays by Murray Edelman (De- 
Table 7. Subfield Distribution of Books Reviewed from 1985 to 1988

\begin{tabular}{lcccc}
\hline & \multicolumn{4}{c}{ Percentage of Books Reviewed } \\
\cline { 2 - 5 } Field & 1985 & 1986 & 1987 & 1988 \\
\hline Political theory & 21 & 18 & 17 & 19 \\
Political economy & $\mathrm{a}$ & 7 & 9 & 6 \\
American politics & 32 & 26 & 27 & 28 \\
Comparative politics & 28 & 25 & 31 & 28 \\
International relations & 19 & 24 & 16 & 19 \\
\hline
\end{tabular}

ancluded in other subfields.

cember 1988), and Charles Cochran (March 1989).

\section{Journal Affairs}

A new edition of the style manual has been completed, with the final preparation of a new version undertaken by Assistant Editor Jean P. Kelly and Copy Editor Michael K. Lane. The new edition, which is called Style Manual for Political Science, was approved by the APSA Publications Committee and has been published by the association. It is available to authors of Review articles, and is available from the American Political Science Association to the political science community.

\section{Volume 82 of the Review}

With Volume 82, the APSR staff continues its commitment to the highest standards for the editing, layout, artwork, and tabular illustration presented in the journal. This volume includes 43 articles, 5 research notes, 5 controversies, 2 review essays, and I symposium-a balance of features very similar to that of the previous volume. Of course, review essays and symposia have a long tradition with the Review, but they are new among issues of recent vintage.

We would like to publish more research notes in the Review. Research notes are short articles that elaborate a new methodological development, replicate earlier research, comment on theoretical issues or concedtual strategy, make a modest contribution in variable definition or measurement. or investigate relatively small but nevertheless interesting questions. Much of the research of political scientists could be presented in the form of research notes rather than full-blown articles. It would be a positive step to establish research notes as contributions of status and to diminish the sometimes bloviated article format to which we have grown so accustomed. Scholars should try harder to render their scientific or conceptual work in the briefer compass suitable for research notes.

\section{The Review in Retrospect}

Over more than eight decades, II scholars have served as managing editors of the APSR. One of them, Frederic A. Ogg, was managing editor for a quarter of a century! These editors, in one degree or another, presided over and helped to shape the development of political science as a discipline, at least in the United States. We take account of these managing editors in Table 8, which also shows book review editors and some indication of the changes that have taken place in the journal in 82 years. But these are only the bare bones. The richer story of the development of the Review is to be found in the reports of these managing editors, and in other documents either published in the APSR or stored in the files of the association. (We thank Jean Walen of the APSA professional staff for tireless work in tracking down the historical material.) It is worth recounting some of this story. 


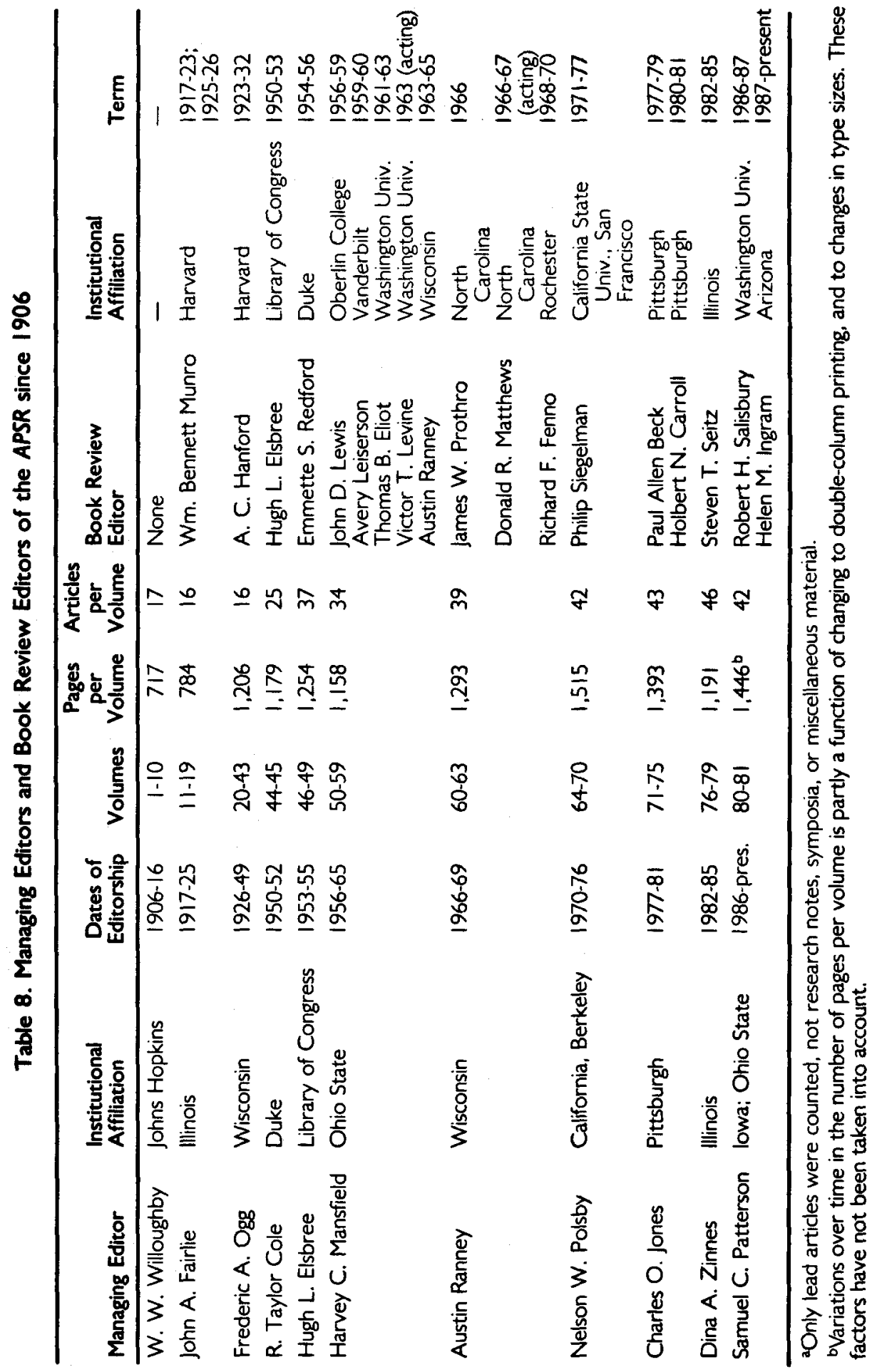


Developmental Years: W. W. Willoughby and John A. Fairlie

The American Political Science Association was founded in 1903 at a meeting in New Orleans. For a number of years, scholarly papers presented at its annual meetings were published in a volume of Proceedings. But there was growing interest in establishing a quarterly journal for political science. According to the report of the association's secretary, interest in founding a journal was expressed by APSA members as early as the second annual meeting. Finally, in November 1906, the American Political Science Review came into existence. Now 82 years old, the Review has weathered considerable change in political science and in the wider world of politics. Over the years a variety of adjustments have been made in the Review, but today it retains a remarkable similarity to its formative stage.

In The Development of American Political Science: From Burgess to Behavioralism (Boston: Allyn \& Bacon, 1967, p. 53) Albert Somit and Joseph Tanenhaus remark about the status of the Review in the formative years:

... publication in the Review did not then carry with it the kudos it does today. Neither the solidly established Political Science Quarterly nor the Annals of the American Academy of Political and Social Science were immediately eclipsed by their johnnycome-lately competitor. During a great deal of the formative period, in fact, the Review was as much a newsletter as a learned jour. nal ... [and] for a good deal of the period, most of the really scholarly articles in political science continued to appear in the Quarterly or the Annols, rather than the Review.

W. W. Willoughby of Johns Hopkins University served as the first editor of the Review. The managing editor was-and still is-selected by the executive council (now simply called the council) of the association. At the outset, the term of the managing editor was indefinite but the first two managing editors, Willoughby and John $A$. Fairlie of the University of Illinois, each served for approximately ten years.

The executive council, on the recommendation of the managing editor, selected an editorial board. Although there is little documentation of the function served by the board during the early years of the Review, individual board members frequently edited various features in the Review. The financial reports of the association suggest that in most years the board met with the managing editor at the annual meeting of the association, and members were given financial compensation for travel expenses incurred in attending the meeting. For instance, the APSA secretary's report for 1911 indicates that a total amount "not to exceed $\$ 250^{\circ}$ " was appropriated for the travel expenses of the eight members of the board and the members of the executive council.

The founders of the Review were relatively young at the time. Beginning his tenure at 39 years old, W. W. Willoughby served as managing editor until 1916 . His colleagues on the editorial board also appear to have been at an early stage in their careers. Fairlie began serving on the editorial board at the age of thirtyfour. He would become the second managing editor of the Review in 1917. A colleague on the board, Charles E. Merriam, was just 32 years old at the outset of his term.

The first board members are now typically remembered for their accomplishments in political science. But in addjtion to their distinguished records of scholarship, a remarkable number of the early members were or would be active and quite visible in the real world of politics. Merriam served on the Chicago City Council for a total of six years over the period from 1909 to 1917, and he made two bids as the Republican candidate for Chicago's mayor. William F. Willoughby, the twin brother of the first managing editor, served on the board in 19/4. W. F. Willoughby had been first treasurer and then secretary of Puerto Rico from 1901 to 1909. Buring his year on the board, he also began his tenure in Peking as constitutional advisor to the Chinese government.

Indeed, there is a striking connection to the Chinese government among the first board members. Paul S. Reinsch was the U.S. minister to China, where he was instrumental in forming the Chinese Polit- 
ical Science Association and served as the first vice-president of the organization. Both Frank J. Goodnow and Managing Editor W. W. Willoughby served as legal advisors to the Chinese government.

The content of the Review in the early years differed substantially from today's content. Relatively little of its space was devoted to "leading articles." In fact, it appears that the original editorial policy of the Review was essentially to print the papers that had been presented at the annual meetings. In a telling query before the executive council at the 1923 annual meeting, Clarence A. Berdahl (speaking for then Managing Editor Fairlie) raised the question of "whether all, or practically all, papers read at the annual meetings should be published to the exclusion of good leading articles submitted from other sources." Berdahl served for one year as acting managing editor when Fairlie was abroad on leave.

Nevertheless, the pages of the Review in its formative years were marked by the journal's connection to the APSA. Much of the material in the Review served to keep the association's members abreast of current events in the United States and abroad, and to keep them posted on activities of the association and its membership. The Review devoted substantial space to accounts of legislative activities at national and state levels, election outcomes, international developments, municipal affairs, and judicial decisions. The "News and Notes" section reported on professional career changes, promotions, publications, some vacations, and even an occasional "breakdown in health."

From the beginning the Review has been provided to all members of the association, with its costs factored into the membership dues. In the early years, it was sometimes a financial burden to the association. Frequently it was necessary to restrict pages in the issues in order to prevent cost overruns. More extraordinarily, in December 1920 the executive council (according to its minutes) "voted that all members of the Association be invited to make a voluntary contribution of $\$ 1$ during the year for support of the Review."

\section{The Ogg Era}

Fairlie retired as managing editor in December 1925. In various respects the editorship of his successor, Frederic $A$. Ogg of the University of Wisconsin differed from that of Willoughby and Fairlie. One obvious feature of Ogg's regime, compared to his predecessors, was his length of service. Ogg was managing editor for 24 years.

The financial condition of the Review had stabilized by the time of Ogg's editorship, but other issues arose. For example, Ogg regularly expressed concern about what he regarded as the suboptimal quality of submitted manuscripts. Although he reported a general increase in the submission rate during his term as editor, Ogg occasionally solicited manuscripts (once at the outset of his term and then during World War II). In 1926 Ogg reported that he had "difficulty in securing really high grade manuscripts," and asked the executive and the editorial board to stimulate quality submissions. Again in 1941 Ogg noted in his annual report that articles printed in the Review had "sustained a reasonably satisfactory level," but he lamented the inactivity of established scholars. He added that "in the most recent years, the number of manuscripts offered by young and inexperienced writers (often graduate students) has increased steadily in proportion to the number offered by established scholars in our field."

In the 1940s, when political scientists "went to war," it became unusually difficult for the Review to operate properly. In his 1942 report to the executive council, Ogg wrote that "war-time distractions have caused first-rate manuscripts to grow even more scarce. . . . many of our best and most dependable reviewers of books have been temporarily lost. . . . labor shortages at our publishing plant have begun to entail some delays. . . , and if the Association's revenues continue to shrink, it may be necessary before the year is over to reduce appreciably the size of issues."

One of Ogg's innovations for the Review 
was to shift from quarterly to every-othermonth publication. From 1932 to 1946 (Vols. 26-40), the journal appeared every other month. Ogg saw a number of advantages to issuing the Review at two-month intervals rather than on a quarterly basis. He spelled these out in his 1931 annual report: "(I) somewhat greater freshness of certain materials when published; (2) greater convenience to members resulting from receiving smaller issues at briefer intervals; (3) greater attractiveness to potential new members or subscribers; and (4) the possibility of increasing the amount of matter published in a year without resulting in issues of inordinate size."

Ogg's innovativeness appeared again in 1943, when the Review began to feature symposia. Ogg referred to this as the first symposium to be published in the Review. Entitled "American Government in Wartime-The First Year," it was published in the February 1943 issue.

While there had been considerable consistency in personnel across the editorial boards of Willoughby and Fairlie, Ogg instituted a policy of changing board members every two years. He followed his policy of rotating board membership most of the time but occasionally reappointed some members, citing their invaluable assistance. Accordingly, several persons returned to board membership after brief absences. Ogg apparently consulted board members individually, but the board did not meet formally. He seems to have thought that it was not feasible for the board-typically consisting of ten members-to meet as a collective body. In his annual report for 1941, Ogg opined that "if it be the opinion that the Board ought to function more actively as a board, consideration should be given to the question of reducing the membership to not more than four members, in addition to the managing editor."

By the mid-1940s considerable criticism of Ogg's editorship had developed. One response to criticism came in 1943 when APSA President William Anderson appointed a committee to study the Review, chaired by Clarence A. Berdahl of the University of Illinois. Berdahl's committee reported to the executive council the next year that criticisms of Ogg were ill founded, concluding that Ogg had "carried an extraordinarily heavy burden under very difficult conditions, for an unusually long period of time, at enormous sacrifice of his own time and energy, and always within a most inadequate budget. " And in a 1950 article in the Review on "The Growth of the American Political Science Review, 1926-1949," Harold Zink lionized Ogg. But restiveness about the Review continued.

In 1948 Ogg requested the executive council search for a successor. At the council's 1949 meeting there was spirited debate over the future of the Review and particularly over "editorial policy." At the 1950 annual meeting some objected that "important and far-reaching decisions with reference to the Review had been made without the benefit of extended discussion at a general meeting of the membership." APSA President Quincy Wright answered this charge by citing the association's constitution, which gave great latitude to the executive council to ensure "an orderly transition" of editors. Under something of a cloud, Ogg announced his retirement, claiming he was neither "satisfied" nor "ashamed" of his tenure as managing editor.

Thereafter, two political scientists served briefly as managing editors, providing a transition from the Ogg era to the post-World War II development of the Review. The first of these transition editors was R. Taylor Cole of Duke University, who had been editor of the Journal of Politics. He was appointed as managing editor for a term of three years and he served only one term. During Cole's editorship quarterly publication was resumed, the staff and editorial board was reorganized, the cover design was changed and new features were added. Thereupon Hugh L. Elsbree, a staff member of the Library of Congress who had been book review editor under Cole, was appointed to and served a three-year term as managing editor.

\section{Post-World War II Adjustments}

By the end of the war, the Review had taken a shape and form influenced by the development of the profession, con- 
straints imposed by the circumstances of the war effort, and Ogg's personal imprint. In addition to articles and book reviews, issues of the Review featured a "News and Notes" section on professional activities and listings of doctoral dissertations, recent publications, and available government documents. In 1947, Ogg himself complained that too much journal space was being devoted to professional news, "which the profession seems to desire, " leaving too little room for articles: "This is one reason why not more than one article in four can be accepted." The Review adopted a smaller print size in 1949 as a means of dealing with the dual problems of expense and insufficient journal space.

The creation of PS in December 1967 helped reduce the backlog of manuscripts that had accumulated. The new journal, devoted to professional news and notes, opened more room in the APSR for articles and was accordingly hailed by Managing Editor Austin Ranney as a "most important and welcome trend."

Most articles in the 1946-50 period bore the earmarks of prewar political science, but the Review also featured articles debating the virtues of a "scientific" approach to the study of politics. For example, a 1946 symposium on "Politics and Ethics" featured Gabriel Almond, then at Brooklyn College, in a debate over the prospects for an "objective" analysis of political life. In addition, in this period many articles concerned the conduct of the war and expectations about postwar reconstruction. A 1945 volume included a special feature on "Political Scientists and the War."

In addition, the journal published articles suggesting that political science become an "applied" policy science. In 1946, for example, the APSR featured a short article by Charles E. Merriam outlining his vision for the postwar era. In "Physics and Politics" Merriam made an impassioned plea for political scientists to work along with atomic scientists in order to devise political solutions to "the bomb." He urged them to emphasize "the pursuit of new political truth and its practical application" and called for work on organizing a world government (1946, 456-57).
Articles on teaching were given a prominent place in the Review during this period in a regular feature called "Instruction and Research." These articles offered innovative and creative methods for teaching various political science objects, and ethical issues in teaching were occasionally featured. For example, in 1948, Clinton Rossiter offered his views on "political indoctrination" in the introductory political science course. Rossiter argued on behalf of political indoctrination, with some qualifications.

Debate surroundirig the content and audience of the Review accelerated as the children of the "behavioral revolution" in political science came more and more to demand a share in the pages of the journal. The rise of formal research techniques in political science has sometimes been a source of consternation for readers-and even for some editors-of the Review. In his last report as managing editor (in September 1965), the late Harvey C. Mansfield commented on his editorial approach to "articles that rest heavily on mathematical methods of analysis" and outlined his implicit decision rules for dealing with these articles:

Their political relevance is sometimes plain enough, and sometimes very difficult to see or assess, considering the heroic and unreal assumptions often necessary to present applications of the methods. If the former, I have tried to be hospitable, however difficult most readers will find them. When they appear to represent triumphs of technique over purpose . . . I have usually said no, on the principle that it will be time enough for the general audience of the Review to cope with the method when it is shown to have helped solve some substantive problem of significant professional concern that did not yield to previous approaches. Fortunately, more specialized outlets are meanwhile available to serve the interests of those whom this policy disappoints. As the boundaries between our discipline and its neighbors-and correspondingly, the criteria of political relevance -grow more and more indistinct, however, the editorial choices become more difficuit. I do not know whether, in this respect, I have run behind or ahead of the needs and wants of the profession.

Earlier Mansfield had rendered his salty 
adumbration of editorial policy by formulating "a reversal of Gresham's law: let the editorial policy of the Review throughout to be to encourage the superior to drive out the not-so-good" (1962, 138). The editorial objective of the journal has never been put more unabashedly.

Austin Ranney, who in 1963 had been selected as book review editor by Mansfield, was appointed managing editor in 1966. The Review took on a new look; Ranney modernized the appearance of the journal, and fully institutionalized the emergent system of peer review of scholarly manuscripts. And while Mansfield apparently consulted referees outside his own department on occasion, Ranney deserves the credit for establishing the peer review system. In 1967 Ranney reported that he had consulted more than 250 referees for submitted manuscripts.

Under Ranney's leadership two important changes transpired. First, the political science profession was growing by leaps and bounds, reflecting the blossoming of colleges and universities in the 1960s. This growth was reflected in a rise in the manuscript submission rate, in pressure for more publication space in the Review, and in booming growth in the circulation of the journal. During Ranney's regime circulation grew from about 12 thousand to about 29 thousand. Second, in appearance and content the APSR came to be about what it is today, consisting mainly of scholarly articles and reviews of scholarly books. The founding of PS by the association and the shift to PS of news, notes, bibliographies, and commenced and completed dissertations opened a substantial amount of space in the Review to accommodate the growing pressure for scholarly publication. By the time he resigned in 1969, Ranney had transformed the Review.

\section{The Post-Ranney Era}

The APSA Council appointed Nelson W. Polsby of the University of California, Berkeley, as managing editor in 1970. He caught the brunt of the intellectual and scientific turmoil and controversy of the late 1960 s and early 1970s. Polsby sought to respond to complex pressures on the jour- nal by accepting a larger number and wider range of manuscripts for publication in the Review and by writing his own editorial column for each issue. During his editorship, the number of submitted manuscripts peaked at 484 in 1972-73. In his distinctive "editorial comment," he took on many of the professional issues of the day in a lively, spirited, and very readable fashion.

Polsby's main organizational contribution as managing editor was to establish the APSR internship. The first graduate student interns were volunteers-." philanthropists all," Polsby said-whose main job it was to check footnotes and quotations for accuracy. These were not always Berkeley graduate students. Some came up from Stanford, and some were postdoctoral students residing in the Bay area. For them, Polsby held forth at a monthly "interns' seminar," or brought in APSR authors to explain how they conducted their research. According to Polsby, the opportunity for professional experience compensated for the "unpaid drudgery" of intern life (197I, 781). Subsequent editors built on Polsby's innovation. Table 9 provides a listing of former APSR interns.

Charles $\mathrm{O}$. Jones, who began his work as managing editor in 1975 while he was at the University of Pittsburgh, designated selected graduate assistants as APSR interns. His interns were paid and they came to take on more varied and substantial staff responsibility for the management and production of the journal. Jones's successors, Dina A. Zinnes and Samuel C. Patterson, have continued the practice. The internship has become an important contribution to the staffing of the Review editorial offices, and it has come to be important to the professional training of selected graduate students.

Jones became managing editor under circumstances in which a large backlog of both article manuscripts and book reviews had accumulated. Early in his editorship, he struggled to adapt the number of accepted manuscripts to the space available in the journal and clear up the backlog in book reviews. Jones put his own imprint on the Review by clothing it in a livelier cover, reshaping the appearance of the 
Table 9. APSR Interns, 1970-present

\begin{tabular}{|c|c|c|c|}
\hline \multirow{2}{*}{$\begin{array}{l}\text { Managing Editor } \\
\text { Nelson W. Polsby }\end{array}$} & \multirow{2}{*}{$\begin{array}{c}\text { Term } \\
1970-76\end{array}$} & \multicolumn{2}{|c|}{ APSR Interns } \\
\hline & & $\begin{array}{l}\text { William Cavala } \\
\text { Samuel Kernell } \\
\text { Jesse McCorry } \\
\text { joseph Martin } \\
\text { Robert Nakamura } \\
\text { Jeffrey Pressman } \\
\text { John Ruggie } \\
\text { Byron Shafer } \\
\text { Jay Starling } \\
\text { Stephen Turett } \\
\text { Robert Butterworth } \\
\text { Steven Blutza } \\
\text { Gerald Clayton } \\
\text { Dorothy Clayton } \\
\text { Craig Garrett } \\
\text { Beverly Kearns } \\
\text { David Laitin } \\
\text { Dan Metlay } \\
\text { Harry Williams } \\
\text { Yvonne Jones } \\
\text { Willam M. Lunch } \\
\text { Alex Radian } \\
\text { lan Lustick } \\
\text { Matthew Pinkus } \\
\text { Brinton Rowdybush } \\
\text { Robert Stumpf } \\
\text { Stephen Van Evera } \\
\text { Arthur Trueger } \\
\text { Peter Cowhey } \\
\text { Jeffrey Hart } \\
\text { Steven Lieberman } \\
\text { Robert Arsenau }\end{array}$ & $\begin{array}{l}\text { Jonathan Bendor } \\
\text { Colin Campbell } \\
\text { Richard Hutcheson III } \\
\text { Richard G. C. Johnston } \\
\text { Harry Kreisler } \\
\text { Christine M. Sierra } \\
\text { Serge Taylor } \\
\text { Stephen Weatherford } \\
\text { Charles Bann } \\
\text { Beth Capell } \\
\text { James I. Lengle } \\
\text { Stuart A. Ross } \\
\text { Shai Feldman } \\
\text { Richard Gunther } \\
\text { Elaine Kamarck } \\
\text { Thomas Reese } \\
\text { Christopher R. Barr } \\
\text { John Q. Johnson } \\
\text { David B. Magleby } \\
\text { Evelyn Deborah Jay } \\
\text { Steven Rosenstone } \\
\text { Kennette Benedict } \\
\text { Donald Chisholm } \\
\text { David G. Dalin } \\
\text { Stephen Genco } \\
\text { David M. Richman } \\
\text { Philip J. Wilson } \\
\text { Paul D. Karps } \\
\text { Jenny Ring } \\
\text { John Zaller } \\
\text { David Flanders }\end{array}$ \\
\hline Charles $O$. Jones & $\mid 977-81$ & $\begin{array}{l}\text { Hizkias Assefa } \\
\text { Felix G. Boni } \\
\text { Gerald M. Callucci } \\
\text { Richard K. Herrmann } \\
\text { Robin R. Jones } \\
\text { David Kozak } \\
\text { Austin Linsley } \\
\text { Deiter Matthes } \\
\text { Constance E. Rea } \\
\text { Sara S. Schramm } \\
\text { Margaret Scranton }\end{array}$ & $\begin{array}{l}\text { J. Christopher Walker } \\
\text { Mark Winer } \\
\text { Cary N. Bloyd } \\
\text { Christopher J. Gosso } \\
\text { Ernesto Isuani } \\
\text { Gary Mucciarone } \\
\text { Kevin Neary } \\
\text { Lewis M. Stern } \\
\text { William C. Ware } \\
\text { Sharon K. Fitzgerald } \\
\text { Susan K. Sowinski }\end{array}$ \\
\hline Dina A. Zinnes & $1982-85$ & $\begin{array}{l}\text { Susan L. Rhodes } \\
\text { Timothy J. Rollins } \\
\text { Robert Jokisch } \\
\text { De Lysa Burnier } \\
\text { Michael H. Le Roy }\end{array}$ & $\begin{array}{l}\text { Elizabeth M. Norville } \\
\text { Bradley Gitz } \\
\text { John Brian Mount } \\
\text { Bruce Nesmith }\end{array}$ \\
\hline Samuel C. Patterson & 1986- & $\begin{array}{l}\text { Stephen Borrelli } \\
\text { Steven C. Poe } \\
\text { Michael S. Bailey } \\
\text { Valerie Martinez }\end{array}$ & $\begin{array}{l}\text { Brian D. Ripley } \\
\text { Barbara Trish } \\
\text { Jessica Adolino } \\
\text { Kevin McGuire }\end{array}$ \\
\hline
\end{tabular}


inside pages, and publishing a series of articles taking stock of important arenas of political research.

Dina A. Zinnes of the University of Illinois assumed the responsibilities of managing editor in 1981. She ushered in the "computer age" for APSR management. With Book Review Editor Steven Seitz, Zinnes orchestrated funding for computer hardware and created appropriate software to expedite several aspects of Review correspondence and editing. In addition to greater reliance on word processing for correspondence with authors and referees, Zinnes and Seitz created a classification and record-keeping system for referees that included information on over six thousand individuals (PS $1985,913)$. Several of these innovations have been continued by Patterson.

The development of the American Polit$i c a l$ Science Review is a reflection of the unfolding of political science as it has come to be practiced in the United States. Those of us who are stewards of our discipline's vehicles for scholarly communication today enjoy a rich legacy. Today's APSR evolved over the years along with the profession of political science. The legacy is real: professional standards are remarkably well-established; the quality of scholarship in political science is high, enviable to other social sciences; every year, hundreds of scholars give their professional advice and judgment to the managing editor without charge, as journal referees. We profoundly appreciate the help we get from colleagues around the world who contribute to the quality of the Review.

The APSR's system of peer review provides an exchange among scholars on a relatively wide scale. About four hundred individuals submit manuscripts yearly to the Review, and several hundred scholars write anonymous critiques of these papers. This "seminar by mail" is a remarkable and important institution. Sometimes the seminar by mail yields articles published in the Review; sometimes it contributes to the strengthening of work that is published in other journals; some- times it provides a training ground which yields future scholarly work of improved quality.

The seminar by mail works especially well in an environment of a plurality of journals. Scholars whose papers are rejected can revise where their critics have uncovered telling flaws, and then submit their papers elsewhere for a second opinion. Some of the specialized journals serve as "vaudeville" for inexperienced academic novices trying to learn the scholar's trade. What is more, the plurality of journals makes possible the best cure for rejection by a journal editor-the Xerox machine. The capacity to xerox more copies of a paper upon receiving the rejection letter, and then to submit it to an alternative journal, helps to preserve the autonomy of the budding scholar, and it relieves the rejecting editor of a terrifying sense of despair that mistakes could be immutable and irredeemable.

Of course, peer review is not infallible, and editors' decision-making can suffer from human error. One of the editor's important functions is to help assure that the system is fair and intellectually honest. The editors, editorial board members, referees, and authors who make up the seminar by mail today are responding admirably to the scholar's "itch to publish," and are engaging in the wholly commendable enterprise of "institutionalized skepticism." Because this system of exchange, judgment, and doubt is generally fair and at least moderately efficient, it deserves praise.

\section{Appendix. Members of the Editorial Board of the American Political Science Review, 1906-1988}

Managing Editor: W. W. Willoughby, Johns Hopkins University, 1906-1916

Philip Brown, Princeton University Herbert Croly, New York City Walter F. Dodd, University of Illinois John A. Fairlie, Harvard University Charles G. Fenwick, Bryn Mawr College Henry J. Ford, Princeton University Ernst Freund, University of Chicago james W. Garner, University of Illinois Frank J. Goodnow, Columbia University 
A. R. Hatton, Western Reserve

Alice N. Holden, Harvard University

John A. Lapp, Indiana Bureau of Legislative Information

John H. Latane, Washington and Lee University

J. M. Mathews, University of Illinois

Emlin McClain. University of lowa

William Bennett Munro, Harvard University

Frederic A. Ogg, University of Wisconsin

Jesse Reeves, University of Michigan

Paul S. Reinsch, University of Wisconsin

W. A. Schaper, University of Minnesota

Benjamin F. Shambaugh, University of lowa

Eugene Wambaugh, Harvard Law School

W. F. Willoughby, Advisor to Chinese

Government, Peking

Manoging Editor: John A. Fairlie,

University of Illinois, 1917-1925

J. D. Barnett, University of Oregon

Francis W. Coker, Ohio State University

Edward S. Corwin, Princeton University

Herbert Croly, New York City

Robert E. Cushman, Cornell University

Walter F. Dodd, University of Chicago

Charles G. Fenwick, Bryn Mawr College

A. C. Hanford, Harvard University

John A. Lapp, Indianapolis

William Bennett Munro, Harvard University

Frederic A. Ogg, University of Wisconsin

Thomas H. Reed, University of California,

University of Michigan

Lindsay Rogers, Columbia University

Victor J. West, Stanford University

C. C. Williamson, New York Public Library

W. W. Willoughby, Johns Hopkins University

\section{Managing Editor: Frederic A. Ogg, University of Wisconsin, 1926-1949}

William Anderson, University of Minnesota

Thomas S. Barclay, Stanford University

Clarence A. Berdahl, University of Illinois

Arthur W. Bromage, University of Michigan

Robert C. Brooks, Swarthmore College

Everett S. Brown, University of Michigan

Franklin L. Burdette, University of Maryland

William S. Carpenter, Princeton University

Eugene P. Chase, Lafayette College

Harwood L. Childs, Princeton University

Francis W. Coker, Yale University

Kenneth C. Cole, University of Washington

Kenneth Colegrove, Northwestern University

Robert E. Cushman, Cornell University

Marshall E. Dimock, University of Chicago

Walter F. Dodd, Yale University; University of Chicago

Clyde Eagleton, New York University

John A. Fairlie, University of Illinois
David Fellman, University of Wisconsin

Oliver P. Field, Indiana University

Russell H. Fitzgibbon, University of California, Los Angeles

Robert K. Gooch, University of Virginia

J. A. C. Grant, University of California, Los Angeles

W. Brook Graves, Temple University

Charles B. Hagan, University of Illinois

Charles G. Haines, University of California, Los Angeles

A. C. Hanford, Harvard University

Robert \}. Harris, Louisiana State University

James Hart, University of Virginia

E. Pendleton Herring, Harvard University

Arthur N. Holcombe, Harvard University

Charles S. Hyneman, University of Illinois

W. C. Johnstone, George Washington University

Clyde L. King, University of Pennsylvania

Walter H. C. Laves, University of Chicago

Arthur W. Macmahon, Columbia University

Roscoe C. Martin, University of Alabama

Fritz Morstein Marx, Queens College, U.S

Bureau of the Budget

Alpheus T. Mason, Princeton University

Frederick A. Middlebush, University of Missouri

John D. Millett, Columbia University

Lennox A. Mills, University of Minnesota

Peter H. Odegard, Amherst College

Louise Overacker, Wellesley College

Charles W. Pipkin, Louisiana State University

James K. Pollock, University of Michigan

Kirk H. Porter, University of lowa

C. Herman Pritchett, University of Chicago

Harold S. Quigley, University of Minnesota

Thomas H. Reed, University of Michigan

Lindsay Rogers, Columbia University

Charles C. Rohlfing, University of

Pennsylvania

Frederick L. Schuman, University of Chicago

Walter J. Shepard, Brookings Graduate

School, Ohio State University

Clyde F. Snider, University of Illinois

Donald C. Stone, U.S. Bureau of the Budget

Russell M. Story, Pomona College

Carl B. Swisher, Johns Hopkins University

Schuyler C. Wallace, Columbia University

Roger H. Wells, Bryn Mawr College

Victor J. West, Stanford University

Leonard D. White, University of Chicago,

Washington, DC

Francis O. Wilcox, Washington, DC

Robert R. Wilson, Duke University

Bruce Williams, University of Virginia

W. W. Willoughby, Johns Hopkins University

Benjamin F. Wright, Harvard University

Managing Editor: $\mathbf{R}$. Taylor Cole,

Duke University, 1950-1952 
Philip W. Buck, Stanford University

Merle Fainsod, Harvard University

James W. Fesler, University of North Carolina

John N. Hazard, Columbia University

Charles S. Hyneman, Northwestern

University

Sigmund Neumann, Wesleyan University

Frederic A. Ogg, University of Wisconsin

Frederick M. Watkins, McGill University

Harold Zink, Ohio State University

Managing Editor: Hugh L. Elsbree,

Librory of Congress, 1953-1955

Taylor Cole, Duke University

Henry Ehrmann, University of Colorado

V. O. Key, Jr., Harvard University

Harvey C. Mansfield, Ohio State University

James L. McCamy, University of Wisconsin

C. Herman Pritchett, University of Chicago

Francis $O$. Wilcox, Washington, DC

\section{Managing Editor: Harvey C. Mansfield,}

\section{Ohio State University, 1956-1965}

Samuel H. Beer (Associate Editor), Harvard University

Rowland Egger, University of Virginia

E. S. Furniss, Jr., Princeton University

Andrew Hacker, Cornell University

Alexander Heard, University of North Carolina

Stanley Hoffmann, Harvard University

Victor Jones, University of California, Berkeley

Otto Kirchheimer, New School for Social

Research; Columbia University

Robert E. Lane, Yale University

Iohn D. Lewis, Oberlin College

Vincent Ostrom, University ut California, Los Angeles

J. Roland Pennock, Swarthmore College

Wallace S. Sayre (Associate Editor), Columbia University

Harold Stein, Princeton University

Leo Strauss, University of Chicago

Dwight Waldo, University of California, Berkeley

\section{Managing Editor: Austin Ranney, University of Wisconsin, 1966-1969}

Fred I. Greenstein, Wesleyan University Robert E. Lane, Yale University Harvey C. Mansfield, Columbia University Warren E. Miller, University of Michigan Walter E. Murdhy, Princeton I Inivercity J. Roland Pennock, Swarthmore College Melvin Richter, City University of New York John E. Turner, University of Minnesota Vernon Van Dyke, University of lowa Myron Weiner, Massachusetts Institute of Technology
Managing Editor: Nelson W. Polsby, University of California, Berkeley, 1970-1976

Alan A. Altshuler, Massachusetts Institute of Technology

Shlomo Avineri, Hebrew University

Lucius Barker, Washington University

Brian Barry, Nuffield College, Oxford University

David Braybrooke, Dalhousie University

Richard A. Brody, Stanford University

Edith T. Carper, The Aerospace Corporation

Samuel D. Cook, The Ford Foundation; Duke University

Elmer E. Cornwell, Brown University

S. Rufus Davis, Monash University

Robert Fried, University of California, Los Angeles

Arthur S. Goldberg, University of Rochester

Morton $\mathrm{H}$. Halperin, Brookings Institution

Robert J. Jackson, Carleton University

Robert Jervis, University of California, Los Angeles

Nannerl O. Keohane, Swarthmore College

Peter Laslett, Trinity. College, Cambridge University

Dale Rogers Marshall, University of California, Davis

Russell D. Murphy, Wesleyan University

Walter F. Murphy, Princeton University

Joan M. Nelson, Woodrow Wilson international Center

Samuel L. Popkin, University of Texas, Austin

$H$. Douglas Price, Harvard University

Robert D. Putnam. University of Michigan

Douglas W. Rae, Yale University

Austin Ranney, University of Wisconsin

Giovanni Sartori, University of Florence

Michael J. Shapiro, University of Hawaii

Paul Sniderman, University of Toronto

Jay Starling, Southern Methodist University

Stephen V. Stephens, Johns Hopkins University

George von der Muhll, University of California, Santa Cruz

Richard A. Watson, University of Missouri

Richard Winters, Dartmouth College

Managing Editor: Charles $O$. Jones, University of Pittsburgh, 1977-1981

Robert M. Axelrod, University of Michigan

Carl Beck, University of Pittsburgh

Steven I. Brams, New York University

Richard A. Brody, Stanford University

William J. Daniels, Union College

Jorge I. Dominguez, Harvard University

Ada W. Finifter, Michigan State University

Dante Germino, University of Virginia

j. Woodford Howard, Johns Hopkins

University 
George A: Kateb, Amherst College

Henry C. Kenski, University of Arizona

Nannerl $O$. Keohane, Stanford University

Anthony King, University of Essex

Gerald $H$. Kramer, Yale University

Arend Lijphart, University of Leiden

Jesse J. McCorry, Washington University;

Department of Health, Education and Welfare

Joseph $O$. Nogee, University of Houston

Elinor Ostrom, Indiana University

Samuel C. Patterson, University of lowa

Nelson W. Polsby, University of California, Berkeley

Kenneth Prewitt, National Opinion Research Center

Jorgen S. Rasmussen, lowa State University

Donald D. Searing, University of North

Carolina

James L. Sundquist, Brookings Institution

Henry Teune, University of Pennsylvania

Edward R. Tufte, Yale University

Susan Welch, University of Nebraska, Lincoln

Dina A. Zinnes, Indiana University

\section{Managing Editor: Dina A. Zinnes,}

University of Illinois, 1982-1985

John $\mathrm{H}$. Aldrich, University of Minnesota

G. Robert Boynton, University of lowa

Naomi Caiden, California State College

David Cameron, Yale University

John Ferejohn, Center for Advanced Study in the Behavioral Sciences

John R. Freeman, Massachusetts Institute of Technology

Sheldon Goldman, University of Massachusetts

Russell L. Hanson, Indiana University

Ruth Jones, Arizona State University

James H. Kuklinski, Stanford University

Mary P. Nichols, Catholic University

Jerrold Rusk, University of Arizona

Barbara Salert, Washington University

Managing Editor: Samuel C. Patterson,

Ohio State University, 1986-present

Susanne Berger, Massachusetts Institute of Technology

David W. Brady, Rice University; Stanford University

Charles V. Hamilton, Columbia University

John R. Hibbing, University of Nebraska,

Lincoln

Harold Jacobson, University of Michigan

Milton G. Lodge, State University of New

York, Stony Brook

John M. Orbell, University of Oregon

$G$. Bingham Powell, jr., University of

Rochester

\author{
Harvey Starr, Indiana University \\ Dennis F. Thompson, Princeton University, \\ Harvard University \\ John C. Wahlke, University of Arizona \\ Raymond Wolfinger, University of California, \\ Berkeley
}

\section{Inauguration of \\ Cornell Professorship Honors First Italian President, Luigi Einaudi}

Luigi Einaudi was the first president of the Republic of Italy, as well as a distinguished economist, courageous opponent of fascism and an early proponent of European unity. A rotating chair professorship created in his name in European and International Studies was inaugurated at Cornell on April 6th with a lecture by French historian Roger Chartier, the first Einaudi chairholder. The Einaudi chair is the first at a major American university to be named for a modern European statesman.

Einaudi, who died in 1961, was president of Italy from 1948 to 1955 and was one of the architects of the country's postwar economic recovery. After joining the faculty of the University of Turin in 1902, he

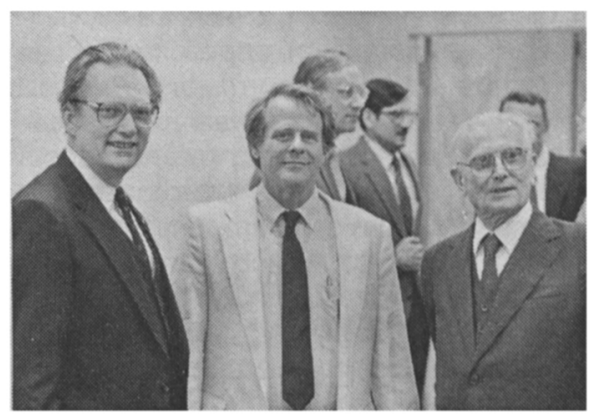

I. to r., Luigi Einaudi (grandson of the late Italian President), Theodore Lowi and Mario Einaudi at the inauguration of the Luigi Einaudi Chair at Cornell University. 